\title{
Influence of the different "patient global assessment" formulations on disease activity score by different indices in Rheumatoid Arthritis
}

Ricardo J. O. Ferreira , ${ }^{* 1,2}$ Gisela Eugénio, ${ }^{* 1}$ Mwidimi Ndosi, ${ }^{3,4}$ Cristiana Silva, ${ }^{5}$ Catarina Medeiros, ${ }^{6}$ Cátia Duarte, ${ }^{1,5}$ J. A. P. da Silva ${ }^{1,5}$

* RJO Ferreira and G Eugénio equally contributed to this study

\section{Departments and Institutions:}

1. Rheumatology Department, Centro Hospitalar e Universitário de Coimbra, Coimbra, Portugal

2. Health Sciences Research Unit: Nursing (UICiSA:E), Escola superior de Enfermagem de Coimbra, Coimbra, Portugal

3. Department of Nursing and Midwifery, University of the West of England, Bristol, UK

4. Academic Rheumatology Unit, University Hospitals Bristol, Bristol, UK

5. Clínica Universitária de Reumatologia, Faculty of Medicine, University of Coimbra, Coimbra, Portugal

6. Internal Medicine Department, Centro Hospitalar Médio Tejo, Unidade de Abrantes.

\section{Corresponding author:}

Ricardo J. O. Ferreira.

Serviço de Reumatologia, Consulta Externa, Piso 7; Centro Hospitalar Universitário de Coimbra, EPE. Avenida Dr Bissaya Barreto, 3000-075 Coimbra. Portugal

email: ferreira.rjo@gmail.com Telephone: 00351965791542

ORCID ID: RJOF - https://orcid.org/0000-0002-2517-0247

MN - https://orcid.org/0000-0002-7764-3173

JAPS - https://orcid.org/0000-0002-2782-6780 


\begin{abstract}
:
Objectives: Patient global assessment (PGA) is included in almost all rheumatoid arthritis (RA) composite disease activity indices and definitions of remission. However, different PGA formulations exist and are used interchangeably in research and clinical practice. We investigated how five different PGA formulations used in four disease indices affect the remission rates.
\end{abstract}

Methods: This was an ancillary analysis of data from a cross-sectional study in patients with RA. The data comprised: 28-joint counts, C-reactive protein and five PGA formulations. Remission rate variation was assessed using five PGA formulations in each index (ACR/EULAR Boolean, CDAI, SDAI and DAS28-CRP). PGA agreement were assessed by: Pearson's correlation; Bland-Altman plots; paired samples t-test; establishing the proportion of patients who scored (i) all formulations within an interval of $20 \mathrm{~mm}$, and (ii) each formulation $\leq 10 \mathrm{~mm}$.

Results: This analysis included 191 patients. PGA formulations presented good correlations $(\geq 0.65)$ but Bland-Altman plots showed clinically significant differences, which were statistically confirmed by comparison of means. Just over a half $(51.8 \%)$ of patients scored all PGA formulations within a $20 \mathrm{~mm}$ interval. The proportion of those scoring $\leq 10 \mathrm{~mm}$ varied from $11.5 \%$ to $16.2 \%$. When different formulations of PGA were used in each index, remission differences of up to $4.7 \%, 4.7 \%, 6.3 \%$, and $5.2 \%$ were observed. When formulations were used in their respective indices, as validated, the remission rates were similar $(13.1 \%, 13.6 \%, 14.1 \%$, and $18.3 \%)$.

Conclusions: Using PGA formulations interchangeably may have implications in the assessment of disease activity and in the attainment of remission and this can impact upon management decisions.

Keywords: Rheumatoid Arthritis, Patient Reported Outcome Measures, Remission Induction, Patient Preference; Disease activity; Patient Global Assessment 


\section{Introduction}

In the last two decades, significant advances have been observed in the treatment of rheumatoid arthritis (RA) as a result not only of the introduction of new therapies but also of new strategies, such as "treat-to-target" (T2T)[1]. Remission, or at least low disease activity (LDA) has become a consensual guiding target for therapy[2-4], as this provides the best assurance of good structural and functional outcomes[5]. Thus, the assessment of disease activity is crucial and the use of combined indices and their cut-offs is recommended to guide and evaluate treatment options, both in research and in clinical practice[2-4].

However, a "gold standard" definition of remission has not been established[2]. The four commonly used definitions are: Disease Activity Score 28 (DAS28)-based remission[4,6], the American College of Rheumatology (ACR)/ European League Against Rheumatism (EULAR) Boolean-based remission, the Clinical Disease Activity Index (CDAI)-based remission, and the Simplified Disease Activity Index (SDAI)-based remission, the last two have been elected as preferential[2,3]. Not surprisingly, different criteria provide different rates of remission[7].

Patient global assessment (PGA) is the only patient-reported outcome (PRO) included in all of the above-mentioned disease activity indices, and considerable attention has been paid recently to its influence on remission rates[8-10]. Several limitations have been pointed out to this assessment, including variations in the: (i) phrasing of the question (e.g. "disease", "arthritis", or "health"; (ii) phrasing of the anchors (e.g. "very well" or "the best"); (iii) type of rating scale (e.g. visual analogue scale (VAS) with $10 \mathrm{~cm}$ or numeric rating scale (NRS) from 0 to 10); and (iv) time intervals to which the evaluation refers (e.g. "last week" or "today")[10,11]. Despite these observations, the different formulations of PGA seem to be used indistinctly in both clinical practice and in research[10].

This study aimed at: (i) evaluating if and how the score of PGA by patients with RA differs according to the formulation of the question, and (ii) assessing the influence of this variability upon remission and LDA rates obtained with four different indices.

\section{Participants and Methods}

Study design \& setting

This was an ancillary analysis of data from an observational, cross-sectional study, performed in a single rheumatology outpatient department[9]. 


\section{Participants}

The original study included consecutive adult patients with a definite diagnosis of RA (ACR 1987 revised criteria or ACR/EULAR 2010 classification criteria). Patients were excluded if they declined participation or if they were unable to respond to the questionnaires unaided. Ethical approval was granted by the Ethics Committee of the Faculty of Medicine, University of Coimbra (CE-037/2015). All patients signed consent according to the Declaration of Helsinki. Additional consent for this ancillary study was not required. Here, data was included from patients who had completed the five versions of PGA and had information for all disease activity indices.

\section{Patient global assessment}

All patients assessed their PGA using the following different formulations:

- "Considering all the ways your arthritis has affected you, how do you feel your arthritis is today?" as recommended by ACR/EULAR[2] (v1).

- "Considering all the ways your arthritis affects you, rate how well you are doing on the following scale" - as in CDAI and SDAI[12] (v2)

- "How well do you consider your health status during the past week?"- as in the original DAS28[13] (v3)

- "How active was your arthritis during the past week?" - as by current DAS28[13] (v4)

- "Your disease has ups and downs. When it is very active ("alight", "scalded/hot"), there is more pain, morning stiffness, joint swelling and tiredness. Taking this into account, how would you rate the state of your disease over the last week?" - PGA formulated by investigators (v5).

All formulations were presented as a 0-100 mm, unmarked, horizontal VAS, with their respective anchors.

\section{Other Variables}

Questionnaires included patient demographic data and other PROs, as described elsewhere[9]. The attending physician provided: tender 28-joint count (TJC28), swollen 28joint count (SJC28), C-reactive protein (CRP) and Physician Global Assessment (PhGA).

Each formulation of PGA was presented in a single page of the questionnaire, interspersed with other PROs to serve as "distractors"[11] and these were completed before clinical consultations. 


\section{Disease activity indices}

The following disease activity indices and respective cut-off points were used to assess remission: (i) ACR/EULAR Boolean-based definition of remission: TJC28, SJC28, CRP (in $\mathrm{mg} / \mathrm{dl}$ ) and PGA (in $\mathrm{cm}$ ) all $\leq 1$ [2], (ii) $\mathrm{SDAI} \leq 3.3[12]$, (iii) $\mathrm{CDAI} \leq 2.8$ [12], and (iv) DAS28CRP<1.9[6]. Cut-offs for LDA state were: $\operatorname{SDAI} \leq 11[12], \mathrm{CDAI} \leq 10[12]$, and DAS28$\mathrm{CRP} \leq 3.1[6]$.

\section{Statistical methods}

Differences across the five PGA formulations were assessed by: (i) Pearson's correlation

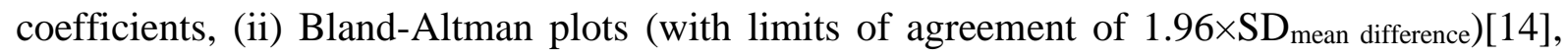
using the ACR/EULAR formulation (v1) as the reference (defined a priori, based on results of a systematic review[10]), (iii) paired samples t-test, comparing the mean scores obtained with each formulation, (v1 used as reference); (iv) examining the proportion of patients who scored all PGA formulations within an interval of $20 \mathrm{~mm}$, (v) comparing the proportion of patients who scored each formulation $\leq 10 \mathrm{~mm}$; (vi) comparing the proportion of patients classified as in remission (and in LDA) according to each formulation; Chi-square test was used to test this difference, namely using indices with their assigned PGA formulation.

\section{Results}

\section{Patient characteristics}

A total of 191 patients were included in this analysis. The demographic and clinical characteristics are presented in Supplementary Table S1. Eighty-three percent of the participants were female, with mean (SD) age: 59(13) years, disease duration: 12(9) years and DAS28-CRP3v: 2.5(1.0). Thirty-four percent were on biologic disease-modifying antirheumatic drugs (bDMARDs).

\section{Differences between PGA formulations}

The correlations between PGA formulations were all good, varying from $r_{p}=0.65$ to $r_{p}=0.80($ all p <0.001) (Supplementary Table S2).

The Bland-Altman plots showed low agreement between formulations, with $95 \%$ limits of variability ranging from [-37.8 to $+30.4 \mathrm{~mm}$ (v2 vs v1)] to [-49.7 to $40.9 \mathrm{~mm}$ (v5 vs v1)] (Supplementary Figure S1).

When comparing mean scores, the two DAS28 formulations obtained the lowest average scores $(42.9 \mathrm{~mm}$ and $42.3 \mathrm{~mm}$, respectively). In contrast, the formulations created by the investigators and the SDAI/CDAI resulted in the highest mean scores $(48.1 \mathrm{~mm}$ and 
$47.2 \mathrm{~mm}$, respectively), presenting a statistically significant difference $(\mathrm{p}=0.0003$ and $\mathrm{p}=0.006$, respectively) when compared with the reference (Table 1).

Ninety-nine patients $(51.8 \%)$ responded to all five formulations within an interval of $20 \mathrm{~mm}$. The ACR/EULAR formulation had the largest number of patients scoring $\leq 10 \mathrm{~mm}$ (16.2\%), while the investigator's and the SDAI/CDAI formulations presented the lowest proportions (11.5\% and $12.0 \%$, respectively) (Table 1$)$.

\section{Differences in Remission rates according to PGA formulations}

When the proper formulations were used in their respective indices, the remission rates were similar in three disease activity indices: $13.1 \%, 13.6 \%$, and $14.1 \%$, respectively for ACR/EULAR Boolean criteria (using v1), CDAI (using v2) and SDAI (using v2). The percentage of patients classified in remission with the DAS28-CRP (using v4) was slightly higher (18.3\%) (Figure 1). Chi-square test revealed, statistically significant differences across all these proportions (Table 2).

When assessing the use of the different formulations in different indices, we observed that the ACR/EULAR formulation was associated with the highest rate of remission in all the four indices. Conversely, the SDAI/CDAI and the Investigator's formulations were associated with the lowest remission rates. The maximum differences in rates of remission with the same index depending on the PGA formulation used (highest minus lowest) were: 4.7\%

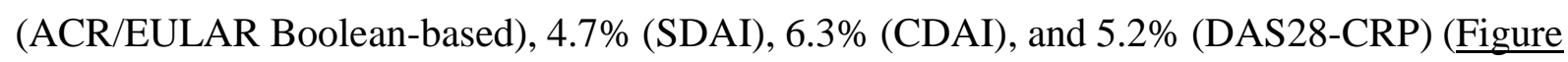

1). Considering the patients that reached at least LDA, the maximum differences between formulations ranged from $2.6 \%$ to $4.8 \%$ according to the index used (Table 3 ).

\section{Discussion}

This study tested how the PGA scored by individual patients with RA varies according to 5 different formulations of this question. We assessed the impact of these formulations upon the rates of remission and LDA defined by different disease indices. These issues have a direct impact upon treatment decisions, according to current recommendations. Although the Pearson's correlations among these formulations were good, the comparison of PGA means values showed statistically significant differences. The $95 \%$ limits of variability revealed by the Bland-Altman plots would probably be considered as relevant by most practicing clinicians. Only approximately half of patients (51.8\%) scored the five PGAs within a 20mm interval. More importantly, differences in remission rates using different formulations of PGA for the same index were significant: for instance, ACR/EULAR Boolean-based remission varied 
between $8.4 \%$ to $13.1 \%$ only by switching between the five versions of PGA; this difference was highest using CDAI, with remission rates varying $13.6 \%$ and $19.9 \%$.

Even though PGA has been widely employed in RA research[10], only few studies[11,15-17] have examined the effect of using different formulations in the assessment of disease activity status. The main conclusions have been, largely, similar in three of these studies[15-17]: although the formulations "are individually not equivalent, they may be used interchangeably for calculating composite indices"[17]. French et al.[11] suggested caution on this interchangeable use of formulations and advocated standardization of PGA. The above studies tested two[16,17], three[15], or five[11] PGA formulations, that resulted in maximum discrepancies in the remission rates of $0.5 \%$ [17], 0.9\%[15], 1.3\%[16], and 4.0\%[11] using DAS28, 1.0\% using CDAI[17], and 0.4\% using Routine Assessment of Patient Index Data 3 (RAPID3)[17], Our study presented higher percentages of variation between formulations: $5.2 \%$ for DAS28 and $6.3 \%$ for CDAI. The main characteristics and results of the previous and present study are summarised in Supplementary Table S3.

The above-mentioned discrepancy between individual study results may be related to different factors, with emphasis on the phrasing of the formulations. In our study, asking "(...) how do you feel your arthritis is today?" (as in ACR/EULAR) led to the highest percentage of remission. However, using a very similar formulation (as in SDAI/CDAI), but without a reference period, the opposite effect was observed. In a qualitative study from our group[18], many patients preferred being asked "today" instead of "last week" because it is easier to recall the symptoms and scoring them. It was rather surprising that the PGA formulation created by the investigators, using a more detailed and culturally adapted explanation was the one with the highest mean value and with fewer patients scoring $\leq 10 \mathrm{~mm}$. A possible explanation was the inclusion of "fatigue", which patients might not otherwise consider a manifestation of RA[8]. Secondly, when using the DAS28, the effect of different PGA formulations is negligible, mostly because of the limited weight that is given to this component[16]. Finally, the levels of disease activity of the samples (influenced by the study design, among other factors) may have influenced the discrepancies, as higher levels of disease activity may be expected to be associated with larger differences between PGA formulations[16]. Our results, however, contradict this assumption given that our sample presented near half levels of disease activity but much higher discrepancies compared with previous studies (Supplementary Table S3). This suggests that culture and educational levels may play an important role in these assessments and these influences should not be ignored[19].

One possible limitation of this study is: the use of VAS instead of NRS in the SDAI/CDAI formulation. Use of VAS (rather than NRS) helped to standardise measures, and 
evidence from previous studies[19,20] suggest that this would not change our conclusions. Another limitation was the presentation of formulations in the same sequence to all patients, although they were interspersed with other scales.

Some important strengths of our study include (i) the use of four disease activity indices and four commonly used PGA formulations (ii) this was the first study to access the influence of the proper PGA formulations in the respective indices (iii) using the updated cut-offs for the DAS28-CRP[6], which allow for a better comparison between the indices and (iv) recruitng patients from clinical practice rather than using data from a clinical trial, as PGA instructions and interpretation by patients may be different in both contexts.

Although the added value of including PGA in the definition of disease activity remission is being debated[21,22], it seem unequivocal, in face of our results, that each formulation of PGA should be limited to the respective disease activity index or, perhaps ideally that the PGA formulation should be standardized into a unique format.

\section{Conflict of interest statement}

Authors declare no conflicts of interest.

\section{Source(s) of support}

This study did not receive any funding.

\section{Acknowledgments}

We thank Sylvie Baptista and João Pedro Sousa for their help in data collection as well as Jorge Silva, Maria João Salvador, Sara Serra, Margarida Coutinho, João Rovisco, Luís Inês, Mariana Santiago, Joana Ferreira, Marília Rodrigues, Carlos Costa, Pedro Carvalho, Alexandra Daniel, Diogo Jesus and Mary Lucy Marques (Coimbra).

We also wish to thank Laure Gossec (Paris) for critically revising the manuscripts for its intellectual content.

We would also like to thank Tracy French, Sarah Hewlett, John Kirwan, and Tessa Sanderson for providing us supplementary information regarding their study. 


\section{References}

1. Smolen JS, Breedveld FC, Burmester GR, Bykerk V, Dougados M, Emery P, Kvien TK, Navarro-Compán MV, Oliver S, Schoels M et al. (2015) Treating rheumatoid arthritis to target: 2014 update of the recommendations of an international task force. Ann Rheum Dis 75 (1):3-15. doi:10.1136/annrheumdis-2015-207524

2. Felson DT, Smolen JS, Wells G, Zhang B, van Tuyl LH, Funovits J, Aletaha D, Allaart CF, Bathon J, Bombardieri S et al. (2011) American College of Rheumatology/European League against Rheumatism provisional definition of remission in rheumatoid arthritis for clinical trials. Ann Rheum Dis 70 (3):404-413. doi:10.1136/ard.2011.149765

3. Smolen JS, Landewe R, Bijlsma J, Burmester G, Chatzidionysiou K, Dougados M, Nam J, Ramiro S, Voshaar M, van Vollenhoven R et al. (2017) EULAR recommendations for the management of rheumatoid arthritis with synthetic and biological disease-modifying antirheumatic drugs: 2016 update. Ann Rheum Dis 76 (6):960-977. doi:10.1136/annrheumdis-2016-210715

4. Singh JA, Saag KG, Bridges SL, Jr., Akl EA, Bannuru RR, Sullivan MC, Vaysbrot E, McNaughton C, Osani M, Shmerling RH et al. (2016) 2015 American College of Rheumatology Guideline for the Treatment of Rheumatoid Arthritis. Arthritis Care Res (Hoboken) 68 (1):1-25. doi:10.1002/acr.22783

5. van Tuyl LH, Felson DT, Wells G, Smolen J, Zhang B, Boers M, American College of Rheumatology, European League against Rheumatism Committee to Define Remission for Clinical Trials (2010) Evidence for predictive validity of remission on long-term outcome in rheumatoid arthritis: a systematic review. Arthritis Care Res (Hoboken) 62 (1):108-117. doi:10.1002/acr.20021

6. Fleischmann R, van der Heijde D, Koenig AS, Pedersen R, Szumski A, Marshall L, Bananis E (2015) How much does Disease Activity Score in 28 joints ESR and CRP calculations underestimate disease activity compared with the Simplified Disease Activity Index? Ann Rheum Dis 74 (6):1132-1137. doi:10.1136/annrheumdis-2013-204920

7. Martins FM, da Silva JA, Santos MJ, Vieira-Sousa E, Duarte C, Santos H, Costa JA, Pimentel-Santos FM, Cunha I, Cunha Miranda L et al. (2015) DAS28, CDAI and SDAI cut-offs do not translate the same information: results from the Rheumatic Diseases Portuguese Register Reuma.pt. Rheumatology (Oxford) 54 (2):286-291. doi:10.1093/rheumatology/keu313

8. Ferreira RJO, Dougados M, Kirwan J, Duarte C, de Wit M, Soubrier M, Fautrel B, Kvien T K, da Silva JAP, Gossec L et al. (2017) Drivers of patient global assessment in patients with rheumatoid arthritis who are close to remission: an analysis of 1588 patients. Rheumatology (Oxford) 56 (9):1573-8 doi:10.1093/rheumatology/kex211

9. Ferreira RJO, Duarte C, Ndosi M, de Wit M, Gossec L, da Silva JAP (2017) Suppressing inflammation in rheumatoid arthritis: Does patient global assessment blur the target? A practice-based call for a paradigm change. Arthritis Care Res (Hoboken). doi:10.1002/acr.23284

10. Nikiphorou E, Radner H, Chatzidionysiou K, Desthieux C, Zabalan C, van Eijk-Hustings Y, Dixon WG, Hyrich KL, Askling J, Gossec L (2016) Patient global assessment in 
measuring disease activity in rheumatoid arthritis: a review of the literature. Arthritis Res Ther 18 (1):251. doi:10.1186/s13075-016-1151-6

11. French T, Hewlett S, Kirwan J, Sanderson T (2013) Different wording of the patient global visual analogue scale (PG-VAS) affects rheumatoid arthritis patients' scoring and the overall disease activity score (DAS28): a cross-sectional study. Musculoskeletal Care 11 (4):229-237. doi:10.1002/msc.1046

12. Aletaha D, Nell VP, Stamm T, Uffmann M, Pflugbeil S, Machold K, Smolen JS (2005) Acute phase reactants add little to composite disease activity indices for rheumatoid arthritis: validation of a clinical activity score. Arthritis Res Ther 7 (4):R796-806. doi:10.1186/ar1740

13. van Riel PL (2014) The development of the disease activity score (DAS) and the disease activity score using 28 joint counts (DAS28). Clin Exp Rheumatol 32 (5 Suppl 85):S-6574

14. Bland JM, Altman DG (1986) Statistical methods for assessing agreement between two methods of clinical measurement. Lancet 1 (8476):307-310

15. Dougados M, Ripert M, Hilliquin P, Fardellone P, Brocq O, Brault Y, Logeart I (2011) The influence of the definition of patient global assessment in assessment of disease activity according to the Disease Activity Score (DAS28) in rheumatoid arthritis. J Rheumatol 38 (11):2326-2328. doi:10.3899/jrheum.110487

16. Koevoets R, Klarenbeek NB, Guler-Yuksel M, van Oosterhout M, van Krugten MV, Kerstens PJ, Huizinga TW, Dijkmans BA, van der Heijde DM, Allaart CF (2011) Simplified versions of the original disease activity score: validation in the BeSt trial. Ann Rheum Dis 70 (8):1471-1474. doi:10.1136/ard.2010.149146

17. Khan NA, Spencer HJ, Abda EA, Alten R, Pohl C, Ancuta C, Cazzato M, Geher P, Gossec L, Henrohn D et al. (2012) Patient's global assessment of disease activity and patient's assessment of general health for rheumatoid arthritis activity assessment: are they equivalent? Ann Rheum Dis 71 (12):1942-1949. doi:10.1136/annrheumdis-2011-201142

18. Henriques M, Duarte C, Ndosi M, Marques A, Silva Jd, Ferreira R (2017) "It can't be zero": a qualitative study of patients' perspective on patient global assessment in rheumatoid arthritis. Ann Rheum Dis 76 (Suppl 2):112. doi:10.1136/annrheumdis-2017-eular.6214

19. Van Tubergen A, Debats I, Ryser L, Londono J, Burgos-Vargas R, Cardiel MH, Landewe R, Stucki G, Van Der Heijde D (2002) Use of a numerical rating scale as an answer modality in ankylosing spondylitis-specific questionnaires. Arthritis Rheum 47 (3):242248. doi:10.1002/art.10397

20. Lati C, Guthrie LC, Ward MM (2010) Comparison of the construct validity and sensitivity to change of the visual analog scale and a modified rating scale as measures of patient global assessment in rheumatoid arthritis. J Rheumatol 37 (4):717-722. doi:10.3899/jrheum.090764

21. van Tuyl LHD, Boers M (2017) Rheumatoid arthritis: Remission - keeping the patient experience front and centre. Nat Rev Rheumatol 13 (10):573-574. doi:10.1038/nrrheum.2017.139 
22. Ferreira RJO, Duarte C, Ndosi M, de Wit M, Gossec L, da Silva JAP (In press) Controversy: The role of patient global assessment (PGA) in the definition of remission in rheumatoid arthritis. Nature Reviews Rheumatology. 
Fig 1 Remission rates according to four disease activity indices using five different formulations of Patient Global Assessment $(n=191)$. The arrows represent the remission rate measured by a disease activity index with its respective PGA formulation.

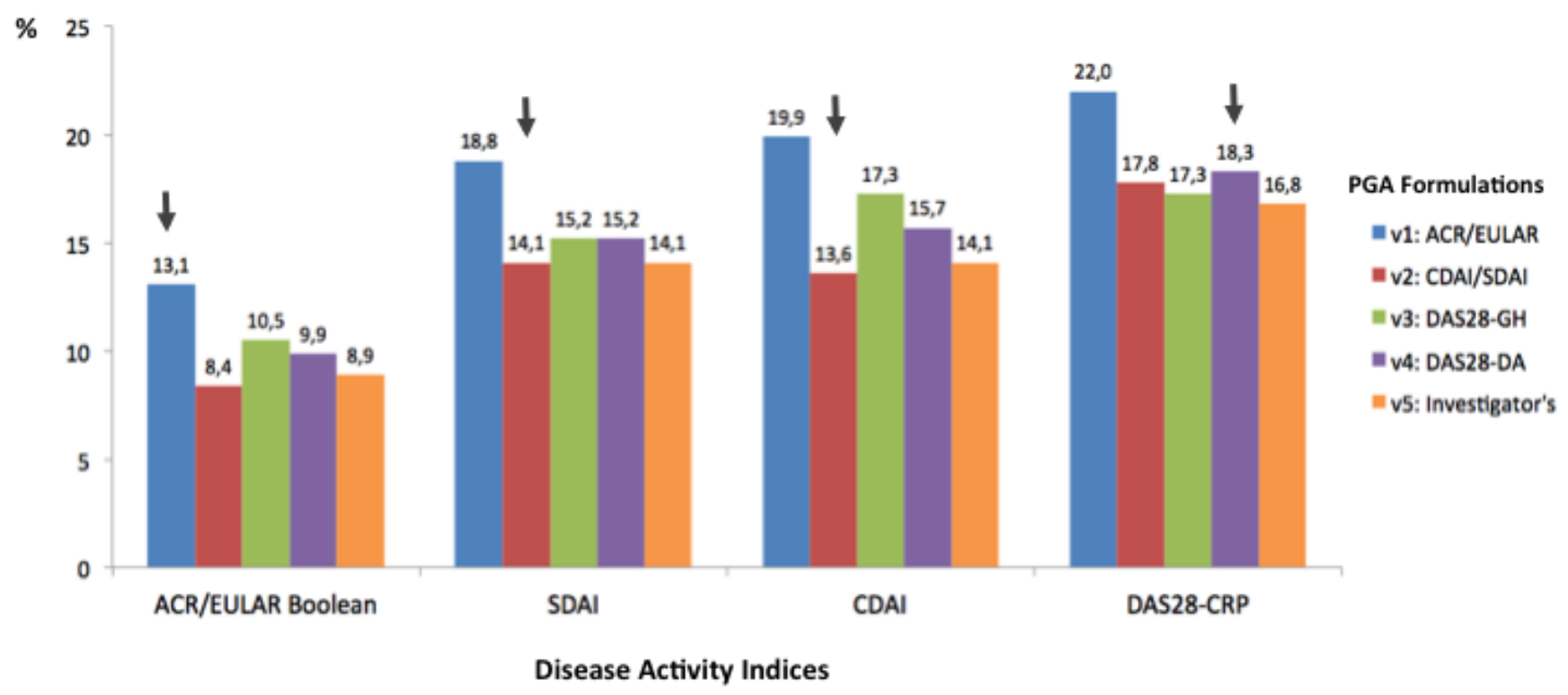


Table 1. Comparison of different PGA formulations with ACR/EULAR version as reference $(n=191)$

\begin{tabular}{|c|c|c|c|c|c|c|}
\hline \multicolumn{4}{|c|}{ Characteristics of the formulations } & \multicolumn{2}{|c|}{$\begin{array}{c}\text { Comparison of mean PGA } \\
\text { scores }\end{array}$} & \multirow{2}{*}{$\begin{array}{c}\mathrm{n}(\%) \text { of } \\
\text { patients } \\
\text { scoring PGA } \\
\leq 10 \mathrm{~mm}\end{array}$} \\
\hline Source & Phrasing & $\begin{array}{c}\text { Reference } \\
\text { period }\end{array}$ & Anchors ${ }^{a}$ & Mean (SD) & p-value ${ }^{c}$ & \\
\hline v1. ACR/EULAR & $\begin{array}{l}\text { "Considering all the ways your arthritis has affected } \\
\text { you, how do you feel your arthritis is today?" }\end{array}$ & Today & $\begin{array}{l}\text { "Very well" and } \\
\text { "Very poor" }\end{array}$ & $43.5(28.0)$ & reference & $31(16.2)$ \\
\hline v2. SDAI/CDAI & $\begin{array}{l}\text { "Considering all the ways your arthritis affects you, } \\
\text { rate how well you are doing on the following scale" }\end{array}$ & $\begin{array}{l}\text { Unspecified } \\
\text { time period }\end{array}$ & $\begin{array}{l}\text { "Very well" and } \\
\text { "Very poor" }\end{array}$ & $47.2(26.0)$ & 0.003 & $23(12.0)$ \\
\hline $\begin{array}{l}\text { v3. DAS original } \\
(\mathrm{GH})\end{array}$ & $\begin{array}{l}\text { "How well do you consider your health status } \\
\text { during the past week?" }\end{array}$ & Last week & $\begin{array}{l}\text { "The best" and } \\
\text { "The worst" }\end{array}$ & $42.9(25.3)$ & 0.697 & $27(14.1)$ \\
\hline $\begin{array}{l}\text { v4. DAS current } \\
\text { (DA) }\end{array}$ & $\begin{array}{l}\text { "How active was your arthritis during the past } \\
\text { week?" }\end{array}$ & Last week & $\begin{array}{l}\text { "Not active at all" and } \\
\text { "Extremely active" }\end{array}$ & $42.3(25.5)$ & 0.400 & $28(14.7)$ \\
\hline $\begin{array}{l}\text { v5. PGA } \\
\text { formulated by the } \\
\text { investigators }\end{array}$ & $\begin{array}{l}\text { "Your disease has ups and downs. When it is very } \\
\text { active ("alight", "scalded/hot"), there is more pain, } \\
\text { morning stiffness, joint swelling and tiredness. } \\
\text { Taking this into account, how would you rate the } \\
\text { state of your disease over the last week?" b }\end{array}$ & Last week & $\begin{array}{l}\text { "Not active at all" and } \\
\text { "Extremely active" }\end{array}$ & $48.1(26.8)$ & 0.006 & $22(11.5)$ \\
\hline \multicolumn{7}{|c|}{$\begin{array}{l}\text { ACR/EULAR: American College of Rheumatology/European League Against Rheumatism; SDAI/CDAI: clinical disease activity index/simplified disease activity index; DA } \\
\text { disease activity score; GH: general health; DA: disease activity; PGA: patient global assessment }\end{array}$} \\
\hline
\end{tabular}


Table 2. Comparison of the proportion of patients in remission between disease activity indices using their respective Patient Global Assessment formulations $(\mathrm{n}=191)$

\begin{tabular}{|c|c|c|c|c|c|c|}
\hline & \multicolumn{3}{|c|}{$\begin{array}{c}\text { ACR/EULAR Boolean-Based } \\
\text { (using v1) }\end{array}$} & \multirow{2}{*}{$\begin{array}{c}\text { Chi-square } \\
\text { test }\end{array}$} & \multirow[t]{2}{*}{ p-value } \\
\hline & & Non-Rem. & Remission & Total & & \\
\hline \multirow{3}{*}{$\begin{array}{c}\text { SDAI } \\
\text { (using v2) }\end{array}$} & Non-Rem. & 156 & 8 & 164 & & \\
\hline & Remission & 10 & 17 & 27 & 68.757 & $<.001$ \\
\hline & Total & 166 & 25 & 191 & & \\
\hline \multirow{3}{*}{$\begin{array}{c}\text { CDAI } \\
\text { (using v2) }\end{array}$} & Non-Rem. & 156 & 9 & 165 & & \\
\hline & Remission & 10 & 16 & 26 & 62.104 & $<.001$ \\
\hline & Total & 166 & 25 & 191 & & \\
\hline \multirow{3}{*}{$\begin{array}{l}\text { DAS28-CRP a } \\
\quad \text { (using v4) }\end{array}$} & Non-Rem. & 146 & 10 & 156 & & \\
\hline & Remission & 20 & 15 & 35 & 33.381 & $<.001$ \\
\hline & Total & 166 & 25 & 191 & & \\
\hline
\end{tabular}

ACR: American College of Rheumatology; CDAI: clinical disease activity index; DA: Disease Activity; DAS28CRP: disease activity score 28-joint count using C-Reactive Protein; EULAR: European League Against Rheumatism; GH: Global Health; PGA: patient global assessment; SDAI: simplified disease activity index.

a. Fleishman's et al.[6] cut-off: remission<1.9

Figures in bold represent the discordant classification between disease activity indices.

Table 3. Proportion of patients in remission and low disease activity states according to the Patient Global Assessment formulations across different clinical disease activity indices $(\mathrm{n}=191)$. Values represent $\mathrm{n}(\%)$.

\begin{tabular}{|c|c|c|c|c|c|c|}
\hline \multirow{3}{*}{$\begin{array}{l}\text { Disease Activity } \\
\text { Indices }\end{array}$} & \multirow{3}{*}{$\begin{array}{c}\text { Disease Activity } \\
\text { Status }\end{array}$} & \multicolumn{5}{|c|}{ PGA Formulations } \\
\hline & & $\mathrm{v} 1$ & v2 & v3 & $\mathrm{v} 4$ & v5 \\
\hline & & ACR/EULAR & SDAI/CDAI & DAS28-GH & DAS28-DA & Investigator's \\
\hline $\begin{array}{l}\text { ACR/EULAR } \\
\text { Boolean-Based }\end{array}$ & Remission $^{a}$ & $25(13.1)$ & $16(8.4)$ & $20(10.5)$ & $19(9.9)$ & $17(8.9)$ \\
\hline \multirow{3}{*}{ SDAI } & Remission & $36(18.8)$ & $27(14.1)$ & $29(15.2)$ & $29(15.2)$ & $27(14.1)$ \\
\hline & LDA & $102(53.4)$ & $107(56.0)$ & $109(57.1)$ & $112(58.6)$ & $106(55.5)$ \\
\hline & Rem. + LDA & $138(72.2)$ & $134(70.1)$ & $138(72.3)$ & $141(73.8)$ & $\underline{133(69.6)}$ \\
\hline \multirow{3}{*}{ CDAI } & Remission & $38(19.9)$ & $26(13.6)$ & $33(17.3)$ & $30(15.7)$ & $27(14.1)$ \\
\hline & LDA & $100(52.4)$ & $108(56.5)$ & $109(57.1)$ & $113(59.2)$ & $106(55.5)$ \\
\hline & Rem. + LDA & $138(72.3)$ & $134(70.1)$ & $142(74.4)$ & $143(74.9)$ & $\underline{133(69.6)}$ \\
\hline \multirow{3}{*}{ DAS28-CRP ${ }^{b}$} & Remission & $42(22.0)$ & $34(17.8)$ & $33(17.3)$ & $35(18.3)$ & $32(16.8)$ \\
\hline & LDA & $91(47.6)$ & $102(53.4)$ & $103(53.9)$ & $101(52.9)$ & $99(51.8)$ \\
\hline & Rem. + LDA & $133(69.6)$ & $136(71.2)$ & $136(71.2)$ & $136(71.2)$ & $131(68.6)$ \\
\hline
\end{tabular}

ACR: American College of Rheumatology; CDAI: clinical disease activity index; DA: Disease Activity; DAS28-

CRP: disease activity score 28-joint count using C-reactive protein; EULAR: European League Against Rheumatism; GH: Global Health; LDA: Low Disease Activity; PGA: patient global assessment; SDAI: simplified disease activity index.

a. Low disease activity is not applicable to this definition.

b. Fleishman's et al. [6] cut-offs: remission $<1.9$ and LDA $\leq 3.1$

Figures in bold represent the higher percentages (per line) and the underlined represent the lowest percentages. 
SUPPLEMENTARY MATERIAL of

Influence of the different "patient global assessment" formulations on disease activity score by different indices in Rheumatoid Arthritis. Ferreira RJO, Eugénio G, Ndosi M, Silva

C, Medeiros C, Duarte C, da Silva JAP

Contact: ferreira.rjo@gmail.com

Supplementary Table 1. Demographic and clinical characteristics of RA patients $(n=191)$.

\begin{tabular}{lcc}
\hline Variable & mean (SD) & $\mathbf{n}(\%)$ \\
\hline Age, years & $59.1(12.9)$ & $158(82.7)$ \\
Number of women & & \\
Years of formal education & $7.5(4.8)$ & 65 (34.2) \\
Disease duration in years & $12.4(9.4)$ & \\
Treated with biologic agents & \\
TJC28 (0-28) & $1.5(3.3)$ \\
SJC28 (0-28) & $1.6(2.8)$ \\
CRP (mg/dl) & $0.8(1.5)$ & \\
PhGA (VAS, 0-100) & $13.3(15.9)$ \\
HAQ (0-3) a & $1.1(0.7)$ \\
DAS28-CRP (3v) & $2.5(1.0)$ \\
\hline $\begin{array}{l}\text { SJC28: swollen 28-joint count; TJC28: tender 28-joint count; CRP: C-reactive protein; PhGA: physician global } \\
\text { assessment; VAS: visual analogue scale; HAQ: health assessment questionnaire; DAS28: disease activity score } \\
\text { with 28-joint counts. } \\
\text { a. Missing data in 2 (1.0\%) patients. }\end{array}$
\end{tabular}


Supplementary Table S2. Pearson's correlations across the five formulations of Patient Global Assessment $(n=191)$. All correlations were significant at $p<0.001$

\begin{tabular}{lcccc}
\hline & $\begin{array}{c}\text { v2 } \\
\text { SDAI/CDAI }\end{array}$ & $\begin{array}{c}\text { v3 } \\
\text { DAS28-GH }\end{array}$ & $\begin{array}{c}\text { v4 } \\
\text { DAS28-DA }\end{array}$ & $\begin{array}{c}\text { v5 } \\
\text { Investigator's } \\
\text { PGA }\end{array}$ \\
\hline v1 ACR/EULAR & .80 & .71 & .75 & .65 \\
v2 SDAI/CDAI & & .67 & .72 & .69 \\
v3 DAS28-GH & & .76 & .65 \\
v4 DAS28-DA & & & .65 \\
ACR: American College of Rheumatology; CDAI: clinical disease activity index; DA: Disease Activity; DAS28: \\
disease activity score 28-joint count; EULAR: European League Against Rheumatism; GH: Global Health; PGA: \\
patient global assessment; SDAI: simplified disease activity index.
\end{tabular}


Supplementary Figure S1 - Bland-Altman plots for agreement (in mm) between ACR/EULAR formulation and the other four Patient Global Assessment formulations ( $\mathrm{n}=191)$.
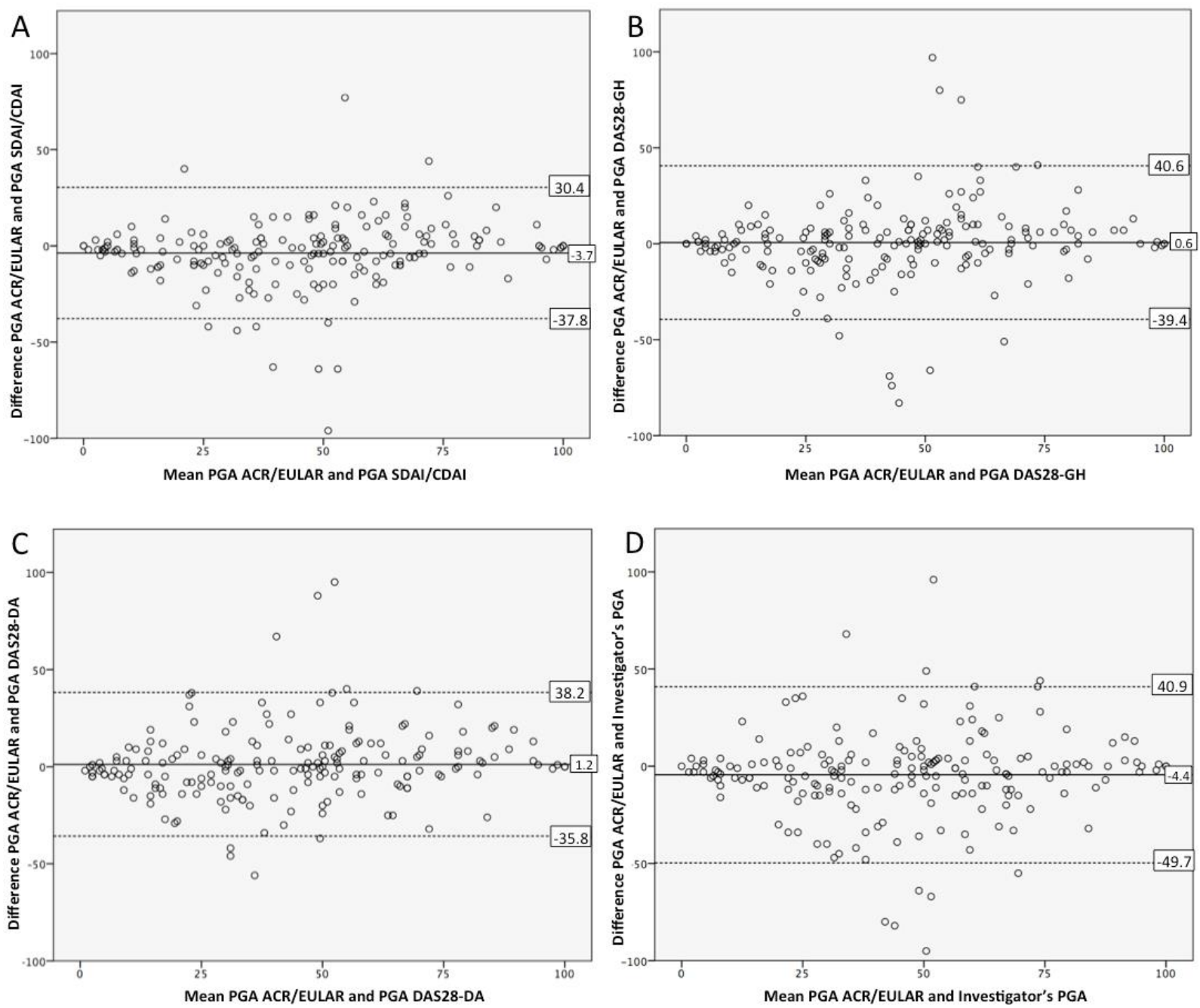

ACR: American College of Rheumatology; CDAI: clinical disease activity index; DA: Disease Activity; DAS28: disease activity score 28-joint count; EULAR: European League Against Rheumatism; GH: Global Health; PGA: patient global assessment; SDAI: simplified disease activity index.

Footnote: The solid line in each plot represents the mean of the difference between the two PGA formulations. The dashed lines demarcate the upper and lower $95 \%$ limits of agreement between them, which were determined by multiplying the standard deviation (SD) of the mean difference by 1.96 . In all plots, the $95 \%$ limits of agreement are considered clinically relevant., using our clinical judgements and published criteria $(11,16)$. 
Supplementary Table S4. Main characteristics and results of studies testing the influence of different formulations of Patient Global Assessment or remission rates

\begin{tabular}{|c|c|c|c|c|c|c|c|c|c|c|c|c|c|c|c|}
\hline \multicolumn{2}{|c|}{ Study } & \multicolumn{4}{|c|}{ Patients } & \multicolumn{3}{|c|}{ Disease } & \multicolumn{4}{|c|}{ PGAs } & \multicolumn{3}{|c|}{ Influence in remission rates } \\
\hline $\begin{array}{c}1^{\text {st }} \text { author } \\
\text { (year), } \\
\text { Country }\end{array}$ & $\begin{array}{l}\text { Design/ } \\
\text { Analysis }\end{array}$ & $\mathbf{n}$ & $\begin{array}{l}\text { Mean } \\
(\mathrm{SD}) \\
\text { Age }\end{array}$ & $\begin{array}{c}\% \\
\text { Fema- } \\
\text { les }\end{array}$ & \begin{tabular}{|c|} 
Educa- \\
tional \\
level
\end{tabular} & $\begin{array}{c}\text { Disease } \\
\text { Dura- } \\
\text { tion }\end{array}$ & $\begin{array}{c}\% \\
\text { treated } \\
\text { biologics }\end{array}$ & $\begin{array}{c}\text { Mean (SD) } \\
\text { Disease } \\
\text { activity }\end{array}$ & Concepts & $\begin{array}{c}\text { Reference } \\
\text { Period }\end{array}$ & $\begin{array}{l}\text { Scoring } \\
\text { Method }\end{array}$ & (Left/ Zero) Anchors & DAI used & Min.** & Max. \\
\hline $\begin{array}{c}\text { Koevoets } \\
(2011), \\
\text { The } \\
\text { Netherlands }\end{array}$ & $\begin{array}{l}\text { RCT/ Long. } \\
\text { (1year) }\end{array}$ & 467 & NA & NA & NA & $\begin{array}{l}100 \% \\
<2 y\end{array}$ & $100 \% *$ & $\begin{array}{c}\text { DAS } \\
\text { Baseline\#: } \\
4.4(0.9)\end{array}$ & $\begin{array}{l}\text { 1) Global Health } \\
\text { 2) Disease Activity }\end{array}$ & NA & NA & NA & $\begin{array}{l}\text { a) DAS } \\
\text { b) } 6 \text { DAS } \\
\text { variations } \\
\text { c) DAS28 }\end{array}$ & $* *$ & $\begin{array}{l}\text { a) } 0.4 \% \\
\text { b) } 0.2 \text { to } \\
1.6 \% \\
\text { c) } 1.3 \%\end{array}$ \\
\hline \begin{tabular}{c|} 
Dougados \\
$(2011)$, \\
France and \\
Monaco
\end{tabular} & $\begin{array}{l}\text { RCT/ } \\
\text { Long. } \\
\text { (12wks) }\end{array}$ & 108 & 54 (13) & $75 \%$ & NA & $8(7)$ & $100 \% *$ & $\begin{array}{c}\text { DAS28(4v) } \\
\text { Baseline\#: } \\
5.4(0.8)\end{array}$ & $\begin{array}{l}\text { 1) Global Health } \\
\text { 2) Disease Activity } \\
\text { 3) Disease Impact (by RAID) }\end{array}$ & $\begin{array}{l}\text { 1) Last 2-3 weeks } \\
\text { 2) Last } 48 \text { hours } \\
\text { 3) Last } 8 \text { days }\end{array}$ & $\begin{array}{l}\text { NRS } \\
0-10\end{array}$ & NA & a) DAS28 & a) $0.0 \%$ & a) $0.9 \%$ \\
\hline $\begin{array}{c}\text { Khan } \\
\text { (2012), } \\
30 \\
\text { Countries }\end{array}$ & $\begin{array}{l}\text { Observ./ } \\
\text { Cross- } \\
\text { sectional }\end{array}$ & 7023 & $55(13)$ & $80 \%$ & $\begin{array}{l}34 \% \\
>12 y\end{array}$ & $11(10)$ & $N A$ & $\begin{array}{l}\text { DAS28: } \\
4.3(1.7)\end{array}$ & $\begin{array}{l}\text { 1) Joint tenderness and Swelling } \\
\text { 2) Global Illness and Health }\end{array}$ & $\begin{array}{l}\text { 1) Today } \\
\text { 2) At this time }\end{array}$ & $\begin{array}{c}\text { VAS } \\
0-10 \mathrm{~cm}\end{array}$ & $\begin{array}{l}\text { 1) Not active } \\
\text { 2) Very well }\end{array}$ & $\begin{array}{l}\text { a) DAS28 } \\
\text { b) CDAI } \\
\text { c) RAPID3 }\end{array}$ & $* *$ & $\begin{array}{l}\text { a) } 0.5 \% \\
\text { b) } 1.0 \% \\
\text { c) } 0.4 \%\end{array}$ \\
\hline $\begin{array}{l}\text { French } \\
\text { (2013), } \\
\text { The UK }\end{array}$ & $\begin{array}{l}\text { Observ./ } \\
\text { Cross- } \\
\text { sectional }\end{array}$ & 50 & $58(14)$ & $78 \%$ & NA & $16(9)$ & $92 \% \pi$ & $\begin{array}{c}\text { DAS28(4v): } \\
4.3(1.5)\end{array}$ & $\begin{array}{l}\text { 1) Feeling (concerning arthritis) } \\
\text { 2) Disease Activity } \\
\text { 3) Well-Being }{ }^{10} \\
\text { 4) Best/Worst }{ }^{11} \\
\text { 5) All ways arthritis affect you }{ }^{12}\end{array}$ & $\begin{array}{l}\text { 1) Last week } \\
\text { 2) This week } \\
\text { 3) This week } \\
\text { 4) Last week } \\
\text { 5) No reference }\end{array}$ & $\begin{array}{c}\text { VAS } \\
0-100 \mathrm{~mm}\end{array}$ & $\begin{array}{l}\text { 1) Very well } \\
\text { 2) Not active at all } \\
\text { 3) Best imaginable health } \\
\text { 4) Best have ever been } \\
\text { 5) Very well }\end{array}$ & a) DAS28 & a) $0.0 \% \pi^{\pi}$ & a) $4.0 \% \%^{\pi}$ \\
\hline $\begin{array}{l}\text { Present } \\
\text { Study }\end{array}$ & $\begin{array}{l}\text { Observ./ } \\
\text { Cross- } \\
\text { sectional }\end{array}$ & 191 & $59(13)$ & $83 \%$ & $\begin{array}{l}15 \% \\
>12 y\end{array}$ & $12(9)$ & $34 \%$ & $\left|\begin{array}{c}\text { DAS28(3v): } \\
2.6(1.2) \\
\text { DAS28(4v): } \\
2.9(1.3)\end{array}\right|$ & $\begin{array}{l}\text { 1) Feeling (concerning arthritis) }{ }^{13} \\
\text { 2) How arthritis affect you }{ }^{14} \\
\text { 3) Global Health } \\
\text { 4) Arthritis activity } \\
\text { 5) Disease (ups \& downs) } \\
\text { activity }^{17}\end{array}$ & $\begin{array}{l}\text { 1) Today } \\
\text { 2) No reference } \\
\text { 3) Last week } \\
\text { 4) Last week } \\
\text { 5) Last week }\end{array}$ & $\begin{array}{c}\text { VAS } \\
0-100 \mathrm{~mm}\end{array}$ & $\begin{array}{l}\text { 1) Very well } \\
\text { 2) Very well } \\
\text { 3) The best } \\
\text { 4) Not active at all } \\
\text { 5) Not active at all }\end{array}$ & $\begin{array}{l}\text { a) ACR/EULAR } \\
\text { Boolean-based } \\
\text { b) SDAI } \\
\text { c) CDAI } \\
\text { d) DAS28 } 8^{\text {IIII }}\end{array}$ & $\begin{array}{l}\text { a) } 0.5 \% \\
\text { b) } 0 \% \\
\text { c) } 0.5 \% \\
\text { d) } 0.5 \%\end{array}$ & $\begin{array}{l}\text { a) } 4.7 \% \\
\text { b) } 4.7 \% \\
\text { c) } 6.3 \% \\
\text { d) } 5.2 \% \text { बIII\% }\end{array}$ \\
\hline
\end{tabular}

ACR/EULAR: American College of Rheumatology/European League Against Rheumatism; CDAI: clinical disease activity index; DAS: disease activity score; DAS28: disease 


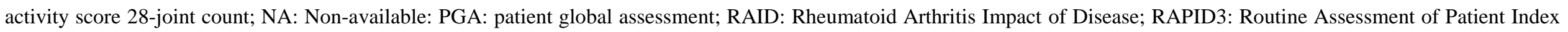
Data 3; RCT: Randomized Controlled Trial; SDAI: simplified disease activity index.

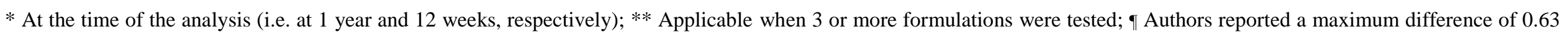

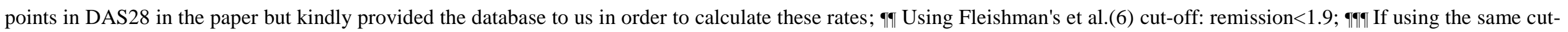
off of other studies $($ rem<2.6) the variation is the same \# DAS28 values not provided for the follow-up periods (i.e. at 1 year and 12 weeks, respectively).

1 - Authors do not specify the wording in the manuscript.

2 - Authors do not specify the wording in the manuscript.

3 - "In general, how would you rate your health over the last 2-3 weeks?"

4 - "Please estimate your disease activity over the last 48 hours"

5 - The "Rheumatoid Arthritis Impact of Disease" score was used, which results from a weightned mean of 7 disease impact domains, ranging from 0 to 10.

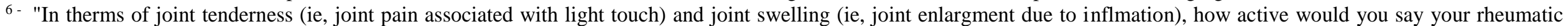
condition is TODAY?"

7 - "Considering all the ways in which illness and health conditions may affect you at this time, please make a mark below to show how you are doing"

8 - " How do you feel concerning your arthritis over the last week?"

9 - "How active has your disease been this week?"

10 - "How has your overall well-being been this week?"

11 - "If 0 is the best you have ever been and 100 is the worst you have ever been, where do you think you have been over the last week?"

12 - "Considering all the ways your arthritis affect you mark on the line bellow how well you are doing."

13 - "Considering all the ways your arthritis has affected you, how do you feel your arthritis is today?"

14 - "Considering all the ways your arthritis affects you, rate how well you are doing on the following scale"

15 - "How well do you consider your health status during the past week?"

16 - "How active was your arthritis during the past week?"

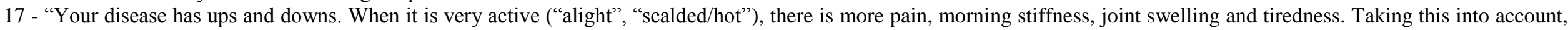
how would you rate the state of your disease over the last week?" 